\title{
PAPER
}

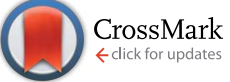

Cite this: J. Mater. Chem. A, 2016, 4, 10524

\section{Crystallisation dynamics in wide-bandgap perovskite films $\dagger$}

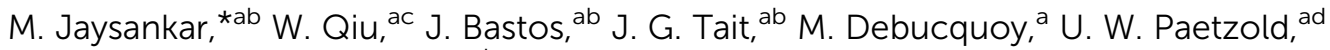 \\ D. Cheyns ${ }^{a}$ and J. Poortmans ${ }^{a b}$
}

\begin{abstract}
Organic-inorganic metal halide perovskite materials have evolved as highly efficient photovoltaic materials with a controllable range of bandgaps. This trait offers exciting prospects for the application of perovskites as wide-bandgap thin-film top solar cells in tandem architectures with crystalline silicon bottom solar cells. In this work, we present a systematic material study on spin-coated methylammonium lead trihalide $\left(\mathrm{CH}_{3} \mathrm{NH}_{3} \mathrm{~Pb}\left(\mathrm{l}_{0.6} \mathrm{Br}_{0.4}\right)_{3}\right)$ that has a band gap of $1.77 \mathrm{eV}$, optimal for tandem architectures with crystalline silicon. Using a combination of $\mathrm{X}$-ray diffraction, time-resolved photoluminescence, and scanning electron microscopy techniques, we determine the strong impact of annealing temperature and duration on perovskite film crystallinity, carrier lifetime, and average grain size. We further demonstrate a clear correlation between solar cell performance and crystallisation dynamics in the perovskite films. With optimised crystallisation of the perovskite films, our solar cells exhibit peak power conversion efficiency of $10.6 \%$ that stabilises at $9.0 \%$ after 10 minutes of maximum power point tracking. Finally, the activation energy for grain boundary mobility, and grain growth exponents are determined via quantitative analysis of grain growth kinetics, and hence, perovskite film quality.
\end{abstract}

Received 4th April 2016

Accepted 7th June 2016

DOI: $10.1039 / \mathrm{c} 6 \mathrm{ta0} 2769 \mathrm{e}$

www.rsc.org/MaterialsA vapour deposition. ${ }^{11-16}$ The deposition techniques used and subsequent post-deposition processes have an immense effect on the overall performance of the solar cells. ${ }^{17}$ The morphology and crystallinity of the perovskite films, which depend on the processing parameters, are of crucial importance for high-efficiency solar cells. ${ }^{18-21}$

By varying the stoichiometry, the material properties of organic-inorganic halide perovskites can be tailored to achieve highly efficient solar cells with a range of bandgaps. In the case of methylammonium lead trihalide, the bandgap can be tuned from $1.55 \mathrm{eV}$ to $2.3 \mathrm{eV}$ by substitution of iodide $\left(\mathrm{I}^{-}\right)$anions by bromide $\left(\mathrm{Br}^{-}\right)$. Increase of the bromine fraction reduces the size of the perovskite unit cell which then alters the electronic energy levels resulting in an increase in the bandgap. ${ }^{22-25}$ It has been shown that for efficient utilisation of the solar spectrum in a tandem configuration with c-Si bottom solar cells, a top cell bandgap between $1.7 \mathrm{eV}$ and $1.8 \mathrm{eV}$ is optimal. ${ }^{26}$

In this work, we analyse the crystallinity, charge carrier lifetimes, and average grain sizes in direct single-step spincoated films of $\mathrm{CH}_{3} \mathrm{NH}_{3} \mathrm{~Pb}\left(\mathrm{I}_{0.6} \mathrm{Br}_{0.4}\right)_{3} \quad\left(\mathrm{MAPI}_{0.6} \mathrm{Br}_{0.4}\right) \quad\left(E_{\mathrm{G}}=\right.$ $1.77 \mathrm{eV}$ ) subjected to different annealing protocols inside an inert $\mathrm{N}_{2}$ atmosphere. The role of annealing temperature and annealing time on the perovskite film quality is analysed using X-ray diffraction (XRD), scanning electron microscopy (SEM), and time-resolved photoluminescence (TRPL) techniques. We then correlate this material knowledge with the electrical performance of the planar glass/ITO/e-beam $\mathrm{TiO}_{2} / \mathrm{MAPI}_{0.6} \mathrm{Br}_{0.4} /$ poly(triaryl amine) (PTAA)/Au solar cells (Fig. S1†).
${ }^{a} I M E C$ - Partner in Solliance, Kapeldreef 75, Leuven, B-3001, Belgium. E-mail: manoj. jaysankar@imec.be

${ }^{b}$ ESAT, KU Leuven, Leuven, B-3001, Belgium

${ }^{c} M T M$, KU Leuven, Leuven, B-3001, Belgium

${ }^{d} I M T$, Karlsruhe Institute of Technology, Eggenstein-Leopoldshafen, 76344, Germany

$\uparrow$ Electronic supplementary information (ESI) available. See DOI: $10.1039 /$ c6ta02769e 


\section{Results and discussion}

\section{Photovoltaic performance}

The evolution of PCE of $\mathrm{MAPI}_{0.6} \mathrm{Br}_{0.4}$ solar cells under AM 1.5G illumination is mapped as a function of annealing temperature and annealing time of the spin-coated perovskite films (Fig. 1a). For a fixed annealing temperature, there is an optimum annealing time to maximize the PCE of the fabricated perovskite solar cells. A similar trend is observed for a fixed annealing time and varying annealing temperature. The solar cells employing $\mathrm{MAPI}_{0.6} \mathrm{Br}_{0.4}$ films annealed at $110{ }^{\circ} \mathrm{C}$ for 90 minutes yielded the highest PCE of $10.6 \%$. The champion cell exhibited a short-circuit current density $\left(J_{\mathrm{SC}}\right)$ of $13.3 \mathrm{~mA} \mathrm{~cm}^{-2}$, an opencircuit voltage $\left(V_{\mathrm{OC}}\right)$ of $1.11 \mathrm{~V}$, and a fill factor of 0.72 (Fig. $1 \mathrm{~b}$ ). The $J_{\mathrm{SC}}$ measured from the $J-V$ scan is comparable to the integrated $J_{\mathrm{SC}}$ of $12.8 \mathrm{~mA} \mathrm{~cm}^{-2}$ estimated from EQE measurements (Fig. 1c). After operation at the maximum power point for 10 minutes, the champion cell yielded a PCE of 9.0\% (Fig. 1d). The drop in PCE under continuous illumination could be attributed to the light-induced phase segregation that has been reported for $\mathrm{MAPI}_{0.6} \mathrm{Br}_{0.4}$ films. ${ }^{27,28}$ Recent studies have shown that widebandgap perovskites based on formamidinium (FA) lead halide alloyed with methylammonium are more photo-stable. ${ }^{29,30}$ It has been proposed that photo-induced ion migration could be reduced in the double alloyed perovskites. This effect coupled with the enhanced thermal stability of FA based perovskites could result in an improved photo-stability of the double alloyed perovskites.

\section{Thin-film characterisation}

We investigated the influence of annealing temperature $\left(80^{\circ} \mathrm{C}\right.$ to $120{ }^{\circ} \mathrm{C}$ ) on the quality of $\mathrm{MAPI}_{0.6} \mathrm{Br}_{0.4}$ films by analysing crystallinity, charge carrier lifetimes, and average grain sizes in films annealed for 90 minutes.

Films annealed at $110{ }^{\circ} \mathrm{C}$ for 90 minutes exhibit sharp and intense XRD peaks that correspond solely to $\mathrm{MAPI}_{0.6} \mathrm{Br}_{0.4}$ (a)

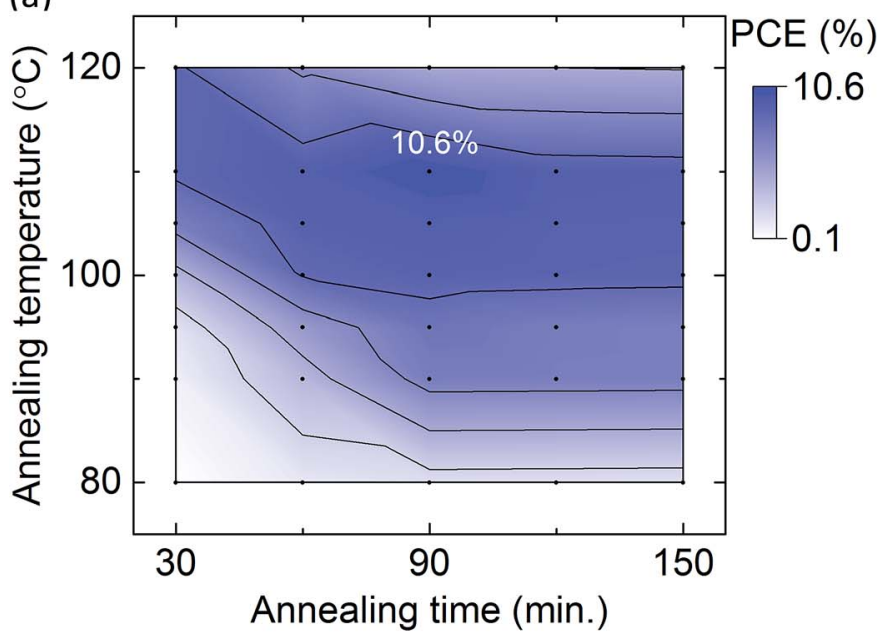

(c)

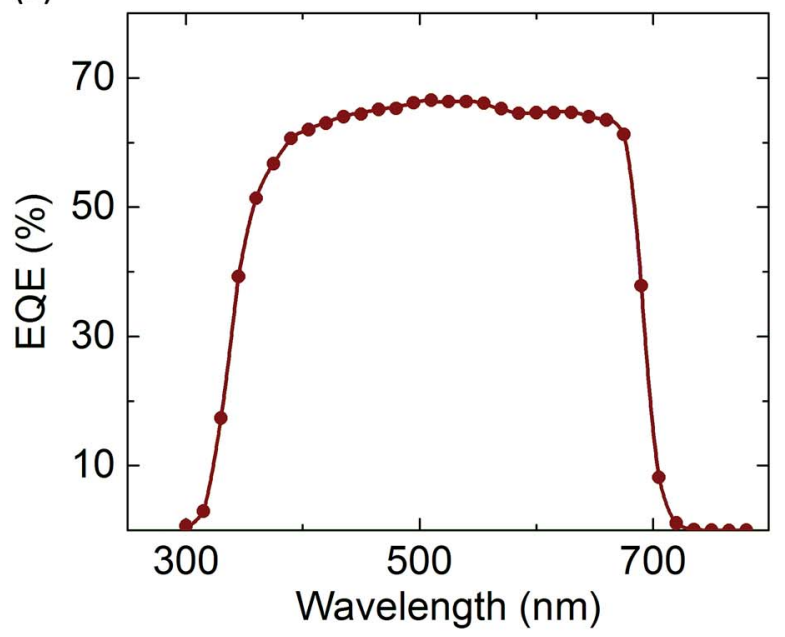

(b)

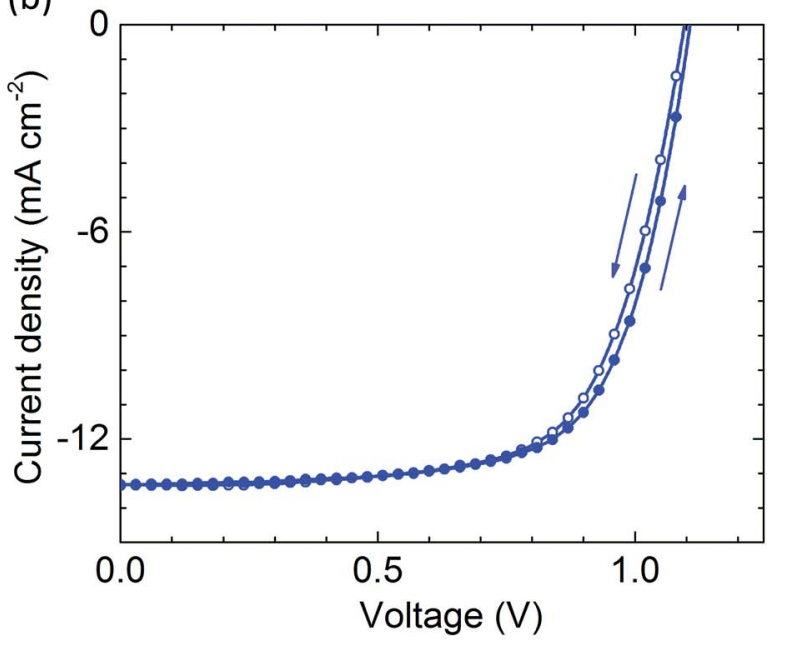

(d)

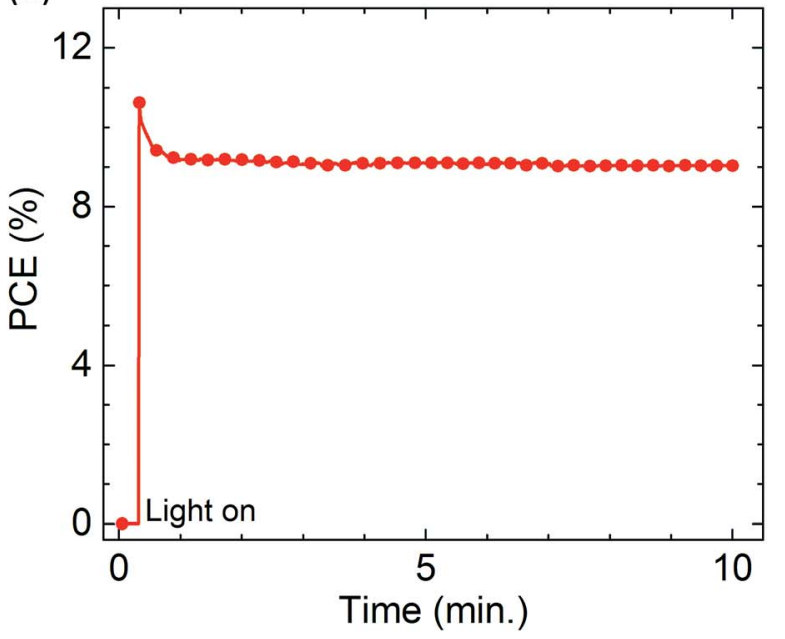

Fig. 1 Variation of power conversion efficiency of ITO/TiO $/ \mathrm{MAPI}_{0.6} \mathrm{Br}_{0.4} / \mathrm{PTAA} / \mathrm{Au}$ solar cells annealed at different temperatures for different durations (a). Current density vs. voltage plot (b), external quantum efficiency (c), and evolution of power conversion efficiency with time tracked at the maximum power point (d) of the champion solar cell employing $\mathrm{MAPI}_{0.6} \mathrm{Br}_{0.4}$ films annealed at $110{ }^{\circ} \mathrm{C}$ for 90 minutes. 
indicating complete conversion of reactants to the desired product (Fig. 2a). The peaks at $14.35^{\circ}$ and $29.04^{\circ}$ correspond to the (100) and (200) planes of crystallised cubic MAPI ${ }_{0.6} \mathrm{Br}_{0.4}$ with a lattice parameter of $6.162 \AA$. Since the ionic radius of $\mathrm{Br}^{-}$ $(1.96 \AA)$ is smaller than that of $\mathrm{I}^{-}(2.2 \AA)$, the lattice parameter in the case of $\mathrm{MAPI}_{0.6} \mathrm{Br}_{0.4}$ is smaller than that reported for MAPI. ${ }^{31}$ As a consequence of the smaller lattice parameter, $\mathrm{MAPI}_{0.6} \mathrm{Br}_{0.4}$ crystallises into a cubic perovskite structure. ${ }^{23,32}$

The films annealed at temperatures below $100{ }^{\circ} \mathrm{C}$ result in incomplete conversion to perovskite. The XRD peaks at $14.81^{\circ}$ and $29.69^{\circ}$ observed at $80{ }^{\circ} \mathrm{C}$ disappear at $90{ }^{\circ} \mathrm{C}$ which leads us to believe that they may be caused by intermediate products of the reaction between the precursors. At $90{ }^{\circ} \mathrm{C}$, the peaks corresponding to the (100) and (200) planes of $\mathrm{MAPI}_{0.6} \mathrm{Br}_{0.4}$ appear and become increasingly intense with higher temperatures.

When the annealing temperature is increased above $110{ }^{\circ} \mathrm{C}$, the peaks corresponding to $\mathrm{PbI}_{2}$ show up at $12.45^{\circ}$ suggesting that the perovskite crystals decompose at those temperatures. The degradation mechanism is similar to that observed in MAPI at temperatures of $120{ }^{\circ} \mathrm{C}$ and above. ${ }^{19,33}$ The formation of $\mathrm{PbI}_{2}$ at high temperatures is explained by the chemical reactions involved in the formation of the perovskite. The perovskite is formed by reacting a salt of lead $\left(\mathrm{PbCl}_{2}, \mathrm{PbBr}_{2}\right)$ with an organic precursor $\left(\mathrm{CH}_{3} \mathrm{NH}_{3} \mathrm{I}, \mathrm{CH}_{3} \mathrm{NH}_{3} \mathrm{Br}\right)$. As mentioned by Dualeh et al., ${ }^{19}$ a by-product of the reaction is $\mathrm{CH}_{3} \mathrm{NH}_{3} \mathrm{Cl}$, which is expected to sublime during annealing and leave behind the desired perovskite as the film. The sublimation rate increases with temperature. However, at high temperatures, the rate of sublimation of the organic precursor, $\mathrm{CH}_{3} \mathrm{NH}_{3} \mathrm{I}$, is also high, which alters the reaction leading to the formation of $\mathrm{PbI}_{2}$. This degradation of $\mathrm{MAPI}_{0.6} \mathrm{Br}_{0.4}$ crystals at temperatures above 110 ${ }^{\circ} \mathrm{C}$ evidently has a detrimental effect on the electrical performance of the solar cells (Fig. 1a).

The morphology of the perovskite films subjected to different annealing temperatures was analysed by SEM and the average grain sizes were extracted using the intercept method based on the ASTM E112-13 standard. As the annealing temperature is raised from $80^{\circ} \mathrm{C}$ to $110{ }^{\circ} \mathrm{C}$, the films become more compact and the average grain sizes increase from $141 \mathrm{~nm}$ to $531 \mathrm{~nm}$ (Fig. 2b). Beyond $110{ }^{\circ} \mathrm{C}$, the nucleation of $\mathrm{PbI}_{2}$ grains due to the transformation of $\mathrm{MAPI}_{0.6} \mathrm{Br}_{0.4}$ causes a saturation of the average grain size. The formation and eventual growth of the $\mathrm{PbI}_{2}$ grains reduce the effective volume of $\mathrm{MAPI}_{0.6} \mathrm{Br}_{0.4}$, which is the active material contributing to the photovoltaic performance of the solar cell. Consequently, a drop in photovoltaic performance is observed for devices in which the perovskite films are annealed at temperatures higher than $110{ }^{\circ} \mathrm{C}$ (Fig. 1a).

To further evaluate the quality of our perovskite films, we extracted the effective carrier lifetime in the films $\left(\tau_{\text {eff }}\right)$ from TRPL measurements. The PL response was measured on perovskite films spin-coated on glass. The films were illuminated with a $532 \mathrm{~nm}$ laser beam and the PL decay at the peak emission wavelength was measured. The $\tau_{\text {eff }}$ increases with annealing temperature up to $110{ }^{\circ} \mathrm{C}$ and decreases for higher annealing temperatures (Fig. 2c). By correlating the values of carrier lifetimes with the phase purity and crystallinity of the perovskite films, we reason that the crystallisation and quality of the perovskite films improve with annealing temperature up to $110{ }^{\circ} \mathrm{C}$, thus increasing the carrier lifetimes. The films annealed at $110{ }^{\circ} \mathrm{C}$ for 90 minutes exhibit the highest $\tau_{\text {eff }}$ (82 ns). The subsequent decrease in $\tau_{\text {eff }}$ beyond $110{ }^{\circ} \mathrm{C}$ is attributed to the formation of $\mathrm{PbI}_{2}$ due to the decomposition of $\mathrm{MAPI}_{0.6} \mathrm{Br}_{0.4}$. This degradation of the active medium results in regions that serve as sites for non-radiative recombination of charge carriers.

Besides the annealing temperature, the annealing time also plays a key role in the formation of good-quality $\mathrm{MAPI}_{0.6} \mathrm{Br}_{0.4}$ films. In order to study the influence of annealing time, we annealed the spin-coated $\mathrm{MAPI}_{0.6} \mathrm{Br}_{0.4}$ films at the optimum temperature of $110{ }^{\circ} \mathrm{C}$ for durations ranging from 30 to 150 minutes. Films annealed for less than 60 minutes show incomplete conversion of precursor materials to the desired perovskite, which is visualised as low intensity peaks in the XRD diffractogram (Fig. 2d). On continuous annealing at $110^{\circ} \mathrm{C}$, the crystallinity of the films improves. The films annealed for 90 minutes exhibit strong peaks corresponding to the cubic $\mathrm{MAPI}_{0.6} \mathrm{Br}_{0.4}$. SEM micrographs (Fig. 2e) indicate an increase of the average grain sizes up to $531 \mathrm{~nm}$ in films annealed for 90 minutes at $110{ }^{\circ} \mathrm{C}$. However, films annealed for more than 90 minutes result in discontinuous grain morphology and pinholes that could be due to the mechanical stress exerted on the films as the grains grow in size. With prolonged annealing, this stress causes the films to lose integrity and results in discontinuous grain morphology. Moreover, a small but measureable shift is observed in the position of XRD peaks in films annealed for 150 minutes. This translates to a change in the lattice parameter of the perovskite unit cell. When compared with films annealed for 90 minutes, the lattice parameter decreases by $0.1 \AA$ in films annealed for 150 minutes. This change in the lattice parameter and the corresponding shift of XRD peaks in over-annealed films are due to the formation of a bromine-rich perovskite phase as a consequence of easier sublimation of the $\mathrm{CH}_{3} \mathrm{NH}_{3} \mathrm{I}$ precursor during annealing. We also notice a shift in the PL peak towards shorter wavelengths in the case of over-annealed films suggesting the formation of the bromine-rich perovskite phase (Fig. S3†). Fig. 2f shows the impact of annealing time on the lifetime of charge carriers in the perovskite films. As expected, the $\tau_{\text {eff }}$ in incompletely annealed perovskite films is lower than that in the optimally annealed films. The presence of pinholes in over-annealed films also has a detrimental effect on the lifetime of charge carriers. Such unfavourable morphology of the active medium evidently affects the charge carrier dynamics and eventually the power conversion efficiency of the solar cells (Fig. 1a). Hence, a fully covered, dense active film is crucial for high efficiency solar cells.

In a polycrystalline system, films with large grains are generally preferred for good charge transport since large grains translate to a small ratio of the grain boundary to the material volume. Grain boundaries are defects in the periodic arrangement of atoms that act as sites of recombination for charge carriers. They are regions of enriched charge traps and should be minimised across the paths of charge transport. ${ }^{20}$ We observe an increase in the $\tau_{\text {eff }}$ in the $\mathrm{MAPI}_{0.6} \mathrm{Br}_{0.4}$ films and 

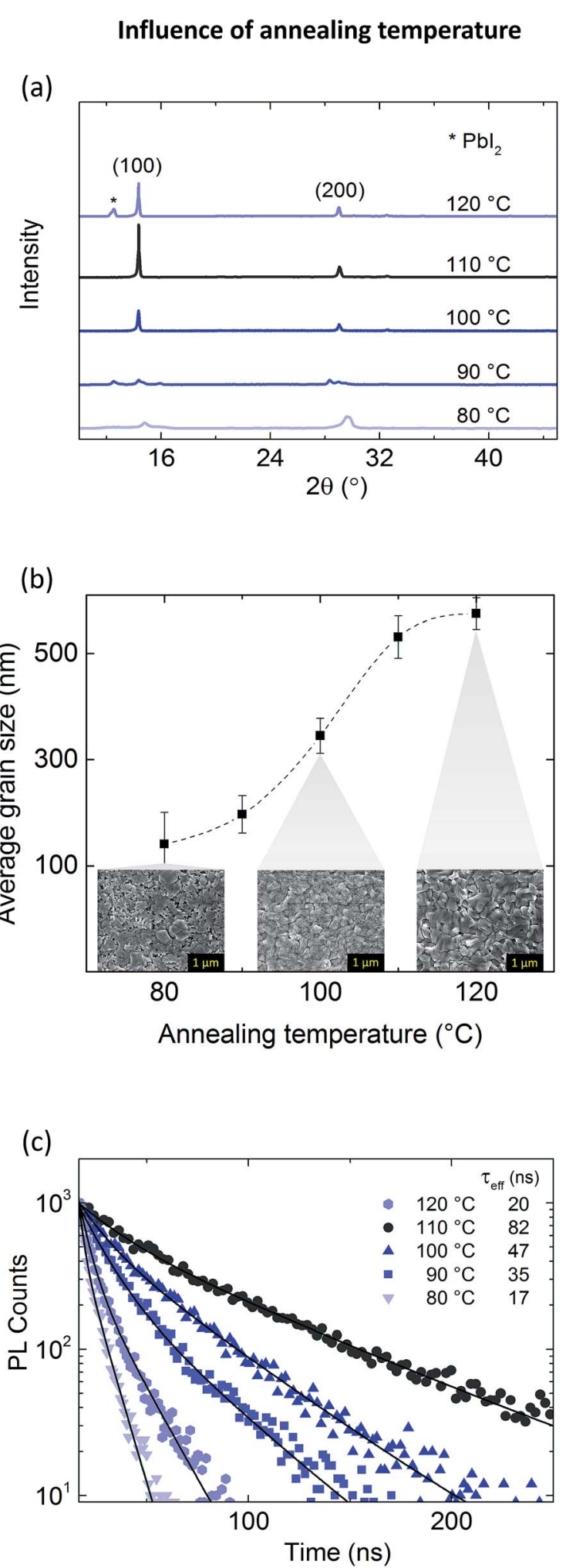
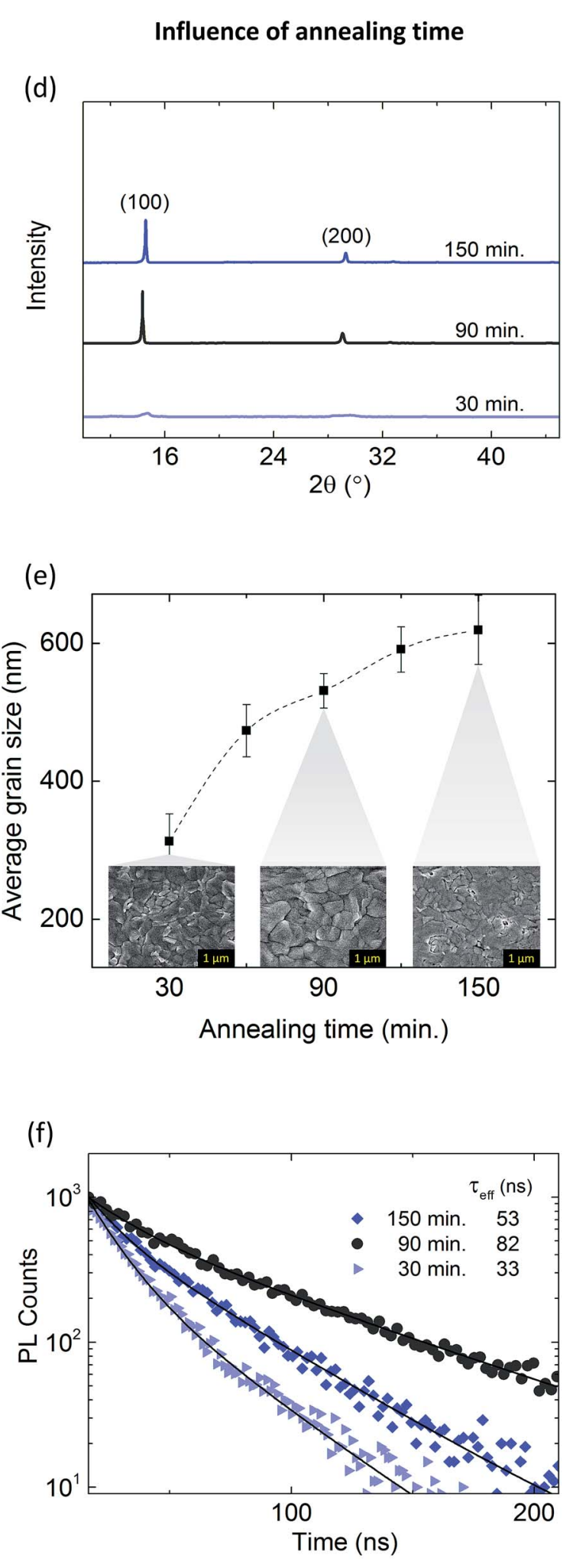

Fig. 2 XRD diffractograms (a and d), SEM micrographs (b and e), and time-resolved photoluminescence decay (c and f) of ITO/TiO $2 / \mathrm{CH}_{3}-$ $\mathrm{NH}_{3} \mathrm{~Pb}\left(\mathrm{I}_{0.6} \mathrm{Br}_{0.4}\right)_{3}$ films annealed at different temperatures for 90 minutes $(\mathrm{a}-\mathrm{c})$ and annealed at $110{ }^{\circ} \mathrm{C}$ for different durations $(\mathrm{d}-\mathrm{f})$. 
a corresponding increase in the $V_{\mathrm{OC}}$ and fill factor of the solar cells as the average size of grains in the active medium increases (Table 1). From this observation, we reason that a less grain boundary area, due to large grains, improves the current collection capability and consequently the PCE of the solar cells. Moreover, perovskite films with small grains exhibit fast decay of photoluminescence signal and have low charge carrier lifetimes, suggesting that grain boundaries function as sites of non-radiative recombination. Hence, reducing the fraction of grain boundaries reduces the number of charge traps and recombination, visualised as an increase in the $V_{\mathrm{OC}}$ of the solar cells. Similar observations have also been reported for MAPI, ${ }^{6,34-38}$ emphasising the importance of grain size on the electrical performance of the solar cells.

\section{Crystallisation dynamics}

In order to gain deeper insight into the fundamental material aspects of $\mathrm{MAPI}_{0.6} \mathrm{Br}_{0.4}$, we examined the grain growth kinetics in the perovskite films. Grain growth is a diffusion process, driven by a reduction in free energy, which leads to an increase in the average grain size of an aggregate of grains. ${ }^{39}$ The reduction in the free energy of the system is caused by reduction of the grain boundary area since a decrease in the grain boundary area decreases the stored energy per unit volume. Consequently, the rate of grain growth is high during the initial minutes and gradually slows down due to lowering of the driving force (Fig. S4†).

The rate at which grains grow is expressed in the form of grain boundary mobility, which is dependent on the activation energy $\left(E_{\mathrm{A}}\right)$ and temperature $(T)$. The growth rate varies directly with temperature and inversely with activation energy. We determine the activation energy for boundary mobility in the $\mathrm{MAPI}_{0.6} \mathrm{Br}_{0.4}$ films by assuming the grain growth to be a thermally activated process and fitting all data with the following grain growth law:

$$
S=k t^{n}
$$

where $S$ is the average grain size at time $t, n$ is the grain growth exponent. $k$ is a temperature dependent constant that follows the exponential relation:

$$
k=k_{0} \exp \left(\frac{-E_{\mathrm{A}}}{R T}\right)
$$

where $k_{0}$ is the rate constant, $E_{\mathrm{A}}$ is the activation energy for grain boundary mobility, $R$ is the universal gas constant, and $T$ is the absolute temperature. In the case of ideal grain growth, the value of the grain growth exponent would be $0.5 .^{40}$ However, oftentimes the value is less than 0.5 owing to factors such as inhomogeneity, phase impurity, dislocations, and boundary mobility anisotropy. ${ }^{40}$ Fig. 3 schematically illustrates the variation of the grain growth exponent in $\mathrm{MAPI}_{0.6} \mathrm{Br}_{0.4}$ films with annealing temperature of the films. The extracted values of the grain growth exponent in the films investigated in this work are tabulated in Table 2 . As the annealing temperature rises, crystallisation of the films improves, increasing the grain growth exponent accordingly. The grain growth exponent is closest to the ideal value of 0.5 in films annealed at $110{ }^{\circ} \mathrm{C}\left(n_{110}=0.46\right)$ which implies a highly uniform crystallisation of the films. Beyond $110{ }^{\circ} \mathrm{C}$, the degradation of $\mathrm{MAPI}_{0.6} \mathrm{Br}_{0.4}$ causes phase

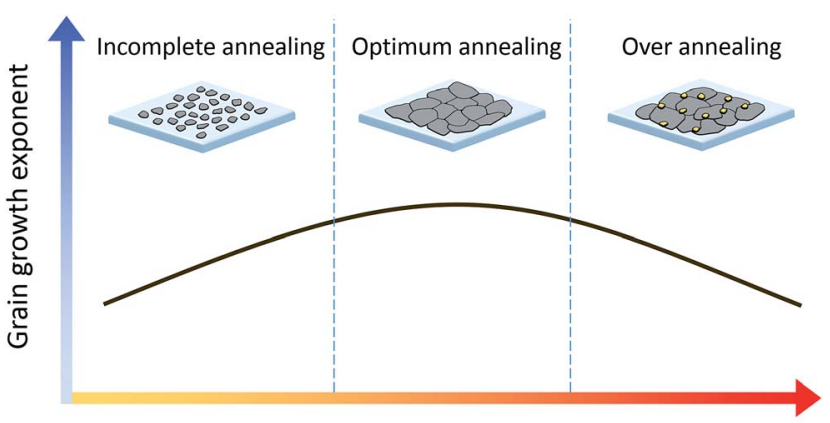

Annealing temperature

Fig. 3 Illustration of the grain growth exponent in perovskite films annealed at different temperatures.

Table 1 Average grain sizes of $\mathrm{CH}_{3} \mathrm{NH}_{3} \mathrm{~Pb}\left(\mathrm{l}_{0.6} \mathrm{Br}_{0.4}\right)_{3}$ films and fill factors of solar cells fabricated with the films (a) annealed at different temperatures for 90 minutes and (b) annealed at $110^{\circ} \mathrm{C}$ for different durations

(a)

\begin{tabular}{lllrrr}
\hline Annealing temperature $\left({ }^{\circ} \mathrm{C}\right)$ & Average grain size $(\mathrm{nm})$ & Fill factor & $V_{\text {OC }}(\mathrm{V})$ & $J_{\text {SC }}\left(\mathrm{mA} \mathrm{cm}^{-2}\right)$ & PCE $(\%)$ \\
\hline 80 & 141 & 0.55 & 0.86 & 2.4 & 1.1 \\
90 & 197 & 0.66 & 0.91 & 1.2 & 12.1 \\
100 & 345 & 0.71 & 1.05 & 1.11 & 9.1 \\
110 & 531 & 0.72 & 0.90 & 9.1 & \\
120 & 575 & 0.55 & & 4.5 \\
\hline
\end{tabular}

\begin{tabular}{|c|c|c|c|c|c|}
\hline Annealing time (min) & Average grain size (nm) & Fill factor & $V_{\mathrm{OC}}(\mathrm{V})$ & $J_{\mathrm{SC}}\left(\mathrm{mA} \mathrm{cm}^{-2}\right)$ & PCE (\%) \\
\hline 30 & 313 & 0.66 & 1.08 & 12.2 & 8.7 \\
\hline 90 & 531 & 0.72 & 1.11 & 13.3 & 10.6 \\
\hline
\end{tabular}

(b) 
Table 2 Values of grain growth exponents in $\mathrm{CH}_{3} \mathrm{NH}_{3} \mathrm{~Pb}\left(\mathrm{I}_{0.6} \mathrm{Br}_{0.4}\right)_{3}$ films annealed at different temperatures

\begin{tabular}{ll}
\hline Annealing temperature $\left({ }^{\circ} \mathrm{C}\right)$ & Grain growth exponent \\
\hline 80 & 0.30 \\
90 & 0.36 \\
100 & 0.41 \\
110 & 0.45 \\
120 & 0.37 \\
\hline
\end{tabular}

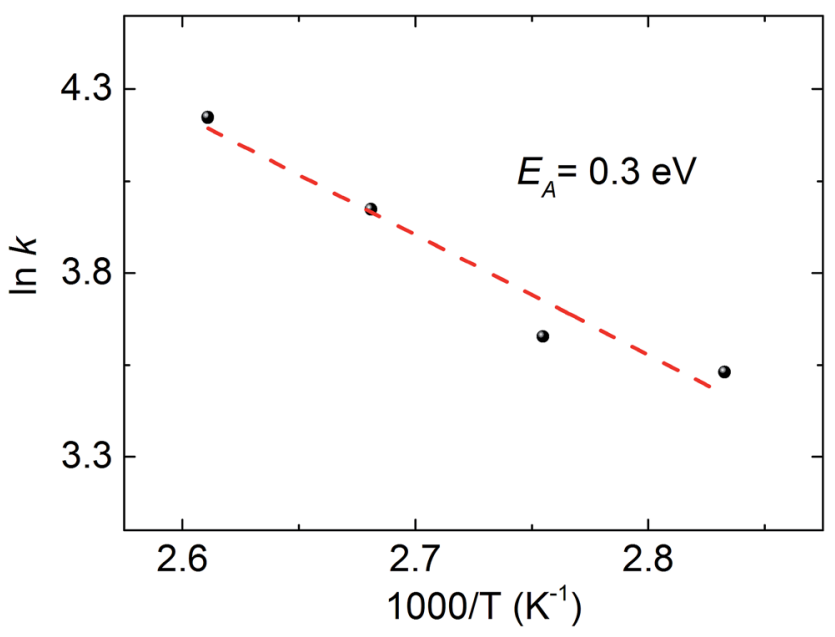

Fig. 4 Plot of In $k$ vs. inverse of temperature fit with a straight line of slope $-E_{\mathrm{A}} / R$.

impurities in the films, as a result of which one set of grains becomes dominant and grows faster than the rest, leading to abnormal grain growth. Thus, the value of the grain growth exponent decreases in films annealed at temperatures higher than $110{ }^{\circ} \mathrm{C}$.

The activation energy for the grain boundary mobility of the cubic MAPI ${ }_{0.6} \mathrm{Br}_{0.4}$ perovskite can be extracted from the plot of ln $k$ vs. $1 / T$ (Fig. 4). The data points are fitted with a linear equation that provides a value of $0.3 \mathrm{eV}$ for the activation energy. The low value of activation energy for grain boundary mobility implies a shallow barrier for atomic diffusion, suggesting that the perovskite material has a fairly open crystal structure and a high grain growth rate. Interestingly, the activation energy for grain boundary mobility extracted for $\mathrm{MAPI}_{0.6} \mathrm{Br}_{0.4}$ films is comparable to the reported values of activation energies for defect movement in MAPI/MAPbBr perovskites. ${ }^{41}$ Similar activation energies for grain growth and defect movement imply that both processes occur at similar rates at typical solar cell operating temperatures and could have a combination of positive and negative effects on the performance of the solar cells.

\section{Conclusion}

A systematic material study on solution processed widebandgap $\mathrm{MAPI}_{0.6} \mathrm{Br}_{0.4}$ films is presented. The impact of annealing temperature and duration on crystallinity, carrier lifetimes, and average grain sizes of the active medium was investigated. The $\mathrm{MAPI}_{0.6} \mathrm{Br}_{0.4}$ films annealed at $110{ }^{\circ} \mathrm{C}$ for 90 minutes resulted in optimal grain morphology. Solar cells fabricated with the optimized perovskite films exhibited a PCE of $10.6 \%$. Moreover, the values of activation energy for grain boundary mobility and grain growth exponents were extracted for $\mathrm{MAPI}_{0.6} \mathrm{Br}_{0.4}$ films annealed at different temperatures. These insights linking the fundamental material characteristics of the perovskite films with device performance are crucial for further development of high-performance perovskite solar cells.

\section{Experimental methods}

\section{Solar cell fabrication}

$3 \mathrm{~cm} \times 3 \mathrm{~cm}$ glass substrates with pre-patterned ITO were purchased from Colorado Concept Coatings LLC. They were cleaned in ultrasonic baths of detergent, de-ionised water, acetone and isopropanol successively for 10 minutes in each bath. The cleaned substrates were loaded into an Angstrom Engineering e-beam evaporation system. $\mathrm{TiO}_{2}$ pellets supplied by Prof. Feierabend $\mathrm{GmbH}$ were evaporated onto the substrates at a rate of $1 \AA \mathrm{s}^{-1}$ while maintaining a partial oxygen pressure of $1.7 \times 10^{-4}$ Torr during the deposition to obtain the desired stoichiometry of the $\mathrm{TiO}_{2}$ layers. $\mathrm{CH}_{3} \mathrm{NH}_{3} \mathrm{~Pb}\left(\mathrm{I}_{0.6} \mathrm{Br}_{0.4}\right)_{3}$ precursor solution with a molarity of $0.8 \mathrm{M}$ was made by stoichiometric mixing of $\mathrm{CH}_{3} \mathrm{NH}_{3} \mathrm{PbI}_{3}$ and $\mathrm{CH}_{3} \mathrm{NH}_{3} \mathrm{PbBr}_{3}$ solutions. The $\mathrm{CH}_{3}$ $\mathrm{NH}_{3} \mathrm{PbI}_{3}$ and $\mathrm{CH}_{3} \mathrm{NH}_{3} \mathrm{PbBr}_{3}$ solutions were made by dissolving $\mathrm{PbCl}_{2}$ (Sigma-Aldrich) and $\mathrm{CH}_{3} \mathrm{NH}_{3} \mathrm{I}$ (Lumtec), and $\mathrm{PbBr}_{2}$ (Sigma-Aldrich) and $\mathrm{CH}_{3} \mathrm{NH}_{3} \mathrm{Br}$ (Lumtec) in $\mathrm{N}, \mathrm{N}$-dimethylformamide. The $\mathrm{CH}_{3} \mathrm{NH}_{3} \mathrm{~Pb}\left(\mathrm{I}_{0.6} \mathrm{Br}_{0.4}\right)_{3}$ solution was then spin-coated at $4000 \mathrm{rpm}$ for $60 \mathrm{~s}$ onto glass/ITO/TiO ${ }_{2}$ layer stacks. The spin coated films were then annealed at various temperatures for different durations on a hot plate inside a nitrogen glovebox. On top of the annealed perovskite films, a solution of poly(triaryl amine) (15 mg in $1.5 \mathrm{~mL}$ chlorobenzene) doped with $15 \mu \mathrm{L}$ lithium bis(tri-fluoromethanesulfonyl) imide $\left(170 \mathrm{mg} \mathrm{mL}^{-1}\right.$ in acetonitrile) and $7.5 \mu \mathrm{L}$ 4-tert-butylepyridine was spin-coated at $1500 \mathrm{rpm}$ for $60 \mathrm{~s}$. The layer stacks were completed by evaporating $80 \mathrm{~nm}$ of gold through shadow masks which resulted in solar cells of $0.13 \mathrm{~cm}^{2}$ active area.

\section{Characterization}

The $J-V$ characteristics of the solar cells were measured in an inert $\mathrm{N}_{2}$ glovebox with a Keithley 2602A Source-Measure Unit and an Abet solar simulator producing $100 \mathrm{~mW} \mathrm{~cm}^{-2}$ simulating AM 1.5G illumination. The solar simulator was calibrated with a KG5 band pass equipped, ISE Fraunhofer certified Si photodiode. The $J-V$ measurement scans were made at a rate of $1 \mathrm{~V} \mathrm{~s}^{-1}$ with a step size of $10 \mathrm{mV}$ per step. The maximum power point tracking was done using the perturb and observe method under continuous AM 1.5G illumination. The EQE was measured with a spectrophotometer setup (Bentham PVE300) by illuminating the solar cell with modulated monochromatic light. X-ray diffraction was performed with a PANalytical X'Pert Pro Materials Research Diffractometer using the $\mathrm{Cu} \mathrm{K} \alpha$ radiation. Scanning electron microscopy images were taken with 
a Philips XL50 scanning electron microscope. Time-resolved photoluminescence measurements were made using a Hamamatsu Near Infrared Compact Fluorescence Lifetime Spectrometer $\mathrm{C} 12132$. The wavelength of the incident light radiation was $532 \mathrm{~nm}$.

\section{Acknowledgements}

This work has been partially supported by Solliance, a partnership of R\&D organizations from the Netherlands, Belgium and Germany working on thin-film photovoltaic solar energy. The work of J. G. Tait was partially supported by the Natural Sciences Engineering and Research Council of Canada under CGSD3454097-2014. The work of U. W. Paetzold was partially supported by the German Academic Exchange Service. The authors declare no competing financial interest.

\section{Notes and references}

1 I. S. E. Fraunhofer, Annu. Rep. 2014/15, 2014, p. 156.

2 J. C. Fan, B. J. Palm and B. Y. Tsaur, Conf. Rec. IEEE Photovolt. Spec. Conf., United States, 1982.

3 T. Soga, T. Kato, M. Yang, M. Umeno and T. Jimbo, J. Appl. Phys., 1995, 78, 4196-4199.

4 N. N. Lal, T. P. White and K. R. Catchpole, IEEE Journal of Photovoltaics, 2014, 4, 1380-1386.

5 S. De Wolf, J. Holovsky, S. J. Moon, P. Löper, B. Niesen, M. Ledinsky, F. J. Haug, J. H. Yum and C. Ballif, J. Phys. Chem. Lett., 2014, 5, 1035-1039.

6 S. D. Stranks, G. E. Eperon, G. Grancini, C. Menelaou, M. J. P. Alcocer, T. Leijtens, L. M. Herz, A. Petrozza and H. J. Snaith, Science, 2013, 342, 341-344.

7 A. Kojima, K. Teshima, Y. Shirai and T. Miyasaka, J. Am. Chem. Soc., 2009, 131, 6050-6051.

8 H. Zhou, Q. Chen, G. Li, S. Luo, T.-B. Song, H.-S. Duan, Z. Hong, J. You, Y. Liu and Y. Yang, Science, 2014, 345, 542-546.

9 N. J. Jeon, J. H. Noh, Y. C. Kim, W. S. Yang, S. Ryu and S. Il Seok, Nat. Mater., 2014, 13, 897-903.

10 W. S. Yang, J. H. Noh, N. J. Jeon, Y. C. Kim, S. Ryu, J. Seo and S. I. Seok, Science, 2015, 348, 1234-1237.

11 J. H. Heo, D. H. Song and S. H. Im, Adv. Mater., 2014, 26, 8179-8183.

12 J. Burschka, N. Pellet, S.-J. Moon, R. Humphry-Baker, P. Gao, M. K. Nazeeruddin and M. Grätzel, Nature, 2013, 499, 316319.

13 Y. Deng, E. Peng, Y. Shao, Z. Xiao, Q. Dong and J. Huang, Energy Environ. Sci., 2015, 8, 1544-1550.

14 A. T. Barrows, A. J. Pearson, C. K. Kwak, A. D. F. Dunbar, A. R. Buckley and D. G. Lidzey, Energy Environ. Sci., 2014, 7, 2944-2950.

15 J. G. Tait, S. Manghooli, W. Qiu, L. Rakocevic, L. Kootstra, M. Jaysankar, C. A. Masse de la Huerta, U. W. Paetzold, R. Gehlhaar, D. Cheyns, P. Heremans and J. Poortmans, J. Mater. Chem. A, 2016, 4, 3792-3797.

16 W. Qiu, T. Merckx, M. Jaysankar, C. Masse de la Huerta, L. Rakocevic, W. Zhang, U. W. Paetzold, R. Gehlhaar,
L. Froyen, J. Poortmans, D. Cheyns, H. J. Snaith and P. Heremans, Energy Environ. Sci., 2016, 9, 484-489.

17 D. Bi, S.-J. Moon, L. Häggman, G. Boschloo, L. Yang, E. M. J. Johansson, M. K. Nazeeruddin, M. Grätzel and A. Hagfeldt, $R S C$ Adv. , 2013, 3, 18762-18766.

18 G. R. Berdiyorov, M. E. Madjet, F. El-Mellouhi and F. M. Peeters, Sol. Energy Mater. Sol. Cells, 2016, 148, 60-66. 19 A. Dualeh, N. Tétreault, T. Moehl, P. Gao, M. K. Nazeeruddin and M. Grätzel, Adv. Funct. Mater., 2014, 24, 3250-3258.

20 S. Mastroianni, F. D. Heinz, J.-H. Im, W. Veurman, M. Padilla, M. C. Schubert, U. Würfel, M. Grätzel, N.-G. Park and A. Hinsch, Nanoscale, 2015, 7, 19653-19662. 21 W. Qiu, U. W. Paetzold, R. Gehlhaar, V. Smirnov, H.-G. Boyen, J. G. Tait, B. Conings, W. Zhang, C. B. Nielsen, I. McCulloch, L. Froyen, P. Heremans and D. Cheyns, J. Mater. Chem. A, 2015, 3, 22824-22829.

22 E. Mosconi, A. Amat, M. K. Nazeeruddin, M. Grätzel and F. De Angelis, J. Phys. Chem. C, 2013, 117, 13902-13913.

23 J. H. Noh, S. H. Im, J. H. Heo, T. N. Mandal and S. Il Seok, Nano Lett., 2013, 13, 1764-1769.

24 S. A. Kulkarni, T. Baikie, P. P. Boix, N. Yantara, N. Mathews and S. Mhaisalkar, J. Mater. Chem. A, 2014, 2, 9221-9225.

25 K. Tanaka, T. Takahashi, T. Ban, T. Kondo, K. Uchida and N. Miura, Solid State Commun., 2003, 127, 619-623.

26 P. Löper, S.-J. Moon, S. Martín de Nicolas, B. Niesen, M. Ledinsky, S. Nicolay, J. Bailat, J.-H. Yum, S. De Wolf and C. Ballif, Phys. Chem. Chem. Phys., 2015, 17, 1619-1629.

27 E. T. Hoke, D. J. Slotcavage, E. R. Dohner, A. R. Bowring, H. I. Karunadasa and M. D. McGehee, Chem. Sci., 2015, 6, 613-617.

28 A. Sadhanala, F. Deschler, T. H. Thomas, S. E. Dutton, K. C. Goedel, F. C. Hanusch, M. L. Lai, U. Steiner, T. Bein, P. Docampo, D. Cahen and R. H. Friend, J. Phys. Chem. Lett., 2014, 5, 2501-2505.

29 Y. Fu, H. Zhu, A. W. Schrader, D. Liang, Q. Ding, P. Joshi, L. Hwang, X.-Y. Zhu and S. Jin, Nano Lett., 2016, 16, 10001008.

30 D. P. McMeekin, G. Sadoughi, W. Rehman, G. E. Eperon, M. Saliba, M. T. Horantner, A. Haghighirad, N. Sakai, L. Korte, B. Rech, M. B. Johnston, L. M. Herz and H. J. Snaith, Science, 2016, 351, 151-155.

31 S. Colella, E. Mosconi, P. Fedeli, A. Listorti, F. Gazza, F. Orlandi, P. Ferro, T. Besagni, A. Rizzo, G. Calestani, G. Gigli, F. De Angelis and R. Mosca, Chem. Mater., 2013, 25, 4613-4618.

32 S. Aharon, B. El Cohen and L. Etgar, J. Phys. Chem. C, 2014, 118, 17160-17165.

33 T. Supasai, N. Rujisamphan, K. Ullrich, A. Chemseddine and T. Dittrich, Appl. Phys. Lett., 2013, 103, 183906.

34 M. Saliba, K. W. Tan, H. Sai, D. T. Moore, T. Scott, W. Zhang, L. A. Estroff, U. Wiesner and H. J. Snaith, J. Phys. Chem. C, 2014, 118, 17171-17177.

35 J. M. Ball, M. M. Lee, A. Hey and H. J. Snaith, Energy Environ. Sci., 2013, 6, 1739-1743.

36 C. Wehrenfennig, G. E. Eperon, M. B. Johnston, H. J. Snaith and L. M. Herz, Adv. Mater., 2014, 26, 1584-1589. 
37 H. Do Kim, H. Ohkita, H. Benten and S. Ito, Adv. Mater., 2016, 28, 917-922.

38 V. D'Innocenzo, A. R. Srimath Kandada, M. De Bastiani, M. Gandini and A. Petrozza, J. Am. Chem. Soc., 2014, 136, 17730-17733.
39 H. V. Atkinson, Acta Metall., 1988, 36, 469-491.

40 F. X. Gil, D. Rodriguez and J. A. Planell, Scr. Metall. Mater., 1995, 33, 1361-1366.

41 J. M. Azpiroz, E. Mosconi, J. Bisquert and F. De Angelis, Energy Environ. Sci., 2015, 8, 2118-2127. 